\title{
THE INFLUENCE OF THE DEFENDANT'S PLEA ON JUDICIAL DETERMINATION OF SENTENCE
}

IN a criminal proceeding, a defendant may plead guilty with the expectation of thereby obtaining reduced punishment for his criminal conduct. ${ }^{1}$ Prosecuting attorneys will often seek a less severe sentence for an accused who does not insist guilt be proven at trial. ${ }^{2}$ The influence of the guilty plea on a prosecutor, and the factors motivating his attitude, are well-explored features of modern criminal administration. ${ }^{3}$ However, commentators have not emphasized the effect of a guilty plea upon a judge vested with discretion in sentencing a defendant. A recent survey by the Yale Law Journal indicates that many judges will give a defendant pleading guilty of a crime a less severe sentence than an accused who has been tried and found guilty of the same offense. Such a practice may co-exist and interact with the concessions accorded by prosecutors to defendants who plead guilty. ${ }^{5}$

\section{The Guilty Plea and the Prosecutor}

As the public representative responsible for prosecution of all criminal offenders, ${ }^{6}$ the prosecuting attorney utilizes the guilty plea as an administra-

1. See, e.g., United States v. Domroe, 129 F.2d 675 (2d Cir. 1942); Hudspeth v. State, 188 Ark. 323, 67 S.W.2d 191 (1933), cert. denied, 296 U.S. 642 (1935); In the Matter of Sabongy, 18 N.J. Super. 334, 87 A.2d 59 (L. 1952); In re Smith, 162 Ohio St. 58, 120 N.E.2d 736 (1954); Sadler v. State, 132 Tex. Crim. 516, 105 S.W.2d 1099 (1937).

2. See Ward v. United States, 116 F.2d 135 (6th Cir. 1940); People v. Ventura, 415 I11. 587, 114 N.E.2d 7.10 (1953); Hobson v. Youell, 177 Va. 906, 914-15, 15 S.E.2d 76, 79 (1941).

Prosecutors may sometimes repudiate their obligation to seek more lenient treatment for a defendant who pleads guilty. See, e.g., State v. Myers, 241 Iowa 670, 42 N.W.2d 79 (1950). Under these circumstances a trial court may be reversed if it refuses to exercise its discretion to allow a guilty plea to be withdrawn. Note, 64 YALE L.J. 590, 594-95 (1955) (federal courts); People v. Barnes, 285 App. Div. 1067, 139 N.Y.S.2d 546 (2d Dep't 1955) ; see People v. King, 1 Ill. 2d 496, 116 N.E.2d 623 (1953). But see State v. Pometti, 23 N.J. Super. 516, 93 A.2d 409 (App. Div. 1952), aff'd on other grounds, 12 N.J. 446, 97 A.2d 399 (1953).

3. E.g., Dash, Cracks in the Fonndation of Criminal Justice, 46 ILL.. L. REv. 385, 392 (1951) ; Hobbs, Prosecutor's Bias, An Occupational Disease, 2 ALA. L. Rev. 40, 41 (1949); Weintraub \& Tough, Lesser Pleas Considered, 32 J. CRIM. L. \& CRIMINoLoGY 506 (1939); Note, The Nolle Prosequi and the Lesser Plea, 33 CoRNeld L.Q. 407 (1948).

4. See text at notes 17-20 infra.

Other empirical evidence supports the conclusion that courts are inclined to treat defendants pleading guilty more leniently. See, e.g., I ILrinors Crrare Survey 84 (1929) (" $[T]$ he chances of getting probation are roughly two and one-half times as great if one pleads guilty to begin with as they are if one pleads not guilty and sticks to it.") ; Newman, Pleading Guilty for Considerations: A Study of Bargain Justice, 46 J. CRrm. L., C. \& P.S. 780,784 (1956).

5. See text at notes 21-22 infra.

6. See, e.g., 28 U.S.C. § 507 (1952); Iowa Code ANN. \$ 336.2 (Supp. 1955) ; MICH. Stat. Anv. c. $39, \$ 5.751$ (Supp. 1955). 
tive tool. ${ }^{7}$ If forced to prove the guilt of every defendant in a judicial proceeding, the prosecutor, with his limited staff and budget, would be hampered in his enforcement of criminal law. ${ }^{8}$ Accordingly, he must secure a waiver of the accused's constitutional right to trial by offering the inducement of more lenient punishment for his criminal acts. ${ }^{9}$

The prosecutor desirous of obtaining guilty pleas may influence the extent of the punishment meted out to the defendant in two different ways. He may request the sentencing judge to award a lenient punishment to a defendant pleading guilty to the crime for which he was indicted.10 Or the prosecutor may permit the defendant to plead guilty to an offense entailing less severe punishment than the crime charged in the initial indictment. ${ }^{11}$ These methods are not equally advantageous to the defendant. An accused who relies upon the prosecutor's request for mercy incurs the risk that the prosecutor may

7. Commentators have emphasized other reasons why prosecutors favor the guilty plea in addition to its contribution to efficient criminal administration. Among these reasons are a desire to achieve an impressive record of convictions and a realization that a conviction at trial is not a certainty regardless of the strength of the prosecutor's case. Dession, Criminal Law Adarinistration and Public Orjer 374-75 (1948); see, generally, Miller, The Compromise of Criminal Cases, 1 So. CalIF. L. REv. 1, 16-22 (1927).

8. Note, 33 Cornell L.Q. 407, 409 (1948); see Note, Prosecutors' Discretion, 103 U. PA. L. REv. 1057, 1070 (1955).

9. A guilty plea is itself a conviction. E.g., Kercheval v. United States, 274 U.S. 220 , 223 (1927) ; United States v. Swaggerty, 218 F.2d 875, 880 (7th Cir.), cert. denied, 349 U.S. 959 (1955); Harrell v. Scheidt, 243 N.C. 735, 744, 92 S.E.2d 182, 188 (1956). Hence the prosecutor need introduce no further evidence after a guilty plea has been entered. E.g., Waley v. United States, 233 F.2d 804 (9th Cir. 1956) ; Tyler v. Warden, 206 Md. 635, 109 A.2d 919 (1954) ; People v. Mason, 307 N.Y. 570, 122 N.E.2d 916 (1954).

10. Ward v. United States, 116 F.2d 135 (6th Cir. 1940) ; People v. Ventura, 415 Ill. 587, 114 N.E.2d 710 (1953); Winchester v. Waters, 97 Okla. Crim. 337, 263 P.2d 535 (1953); see Newman, supra note 4, at 787-88.

11. See People v. Schoenhardt, 206 Misc. 946, 948, 135 N.Y.S.2d 730, 732 (County Ct. 1954) ; see, generally, Newman, supra note 4, at 787; Note, 33 CoRivel L.Q. 407 (1948).

The various types of assault and battery exemplify statutory classifications enabling pleas to lesser included offenses. For example, in Pennsylvania there are four kinds of assaults defined: assault and battery, punishable by a fine of not more than $\$ 1000$ and/or imprisonment up to two years, PA. Stat. AnN. tit. 18, $\$ 4708$ (Supp. 1955); aggravated assault and battery, punishable by a fine of not more than $\$ 2000$ and/or imprisonment up to three years, $i d$. $\$ 4709$; assault with intent to maim, punishable by a fine of not more than $\$ 2000$ and/or imprisonment up to five years, $i d$. $\$ 4712$; assault with intent to kill, punishable by a fine of not more than $\$ 3000$ and/or imprisonment up to seven years, id. $\$ 4710$.

The willingness of the prosecutor to accept a plea to a lesser offense may be predicated upon the greater difficulty of proof of the more aggravated charge. See Dession, op. cit. supra note 7, at 375 .

Sometimes a prosecutor will drop one count of a multi-count indictment rather than allow a plea to a less serious offense than that originally charged. Newman, supra note 4, at 787; see also United States v. Paolantonio, Crim. No. 9049, D. Conn., Jan. 1955; United States v. Santos, Crim. No. 8996, D. Conn., Sept. 24, 1954. 
later breach his promise to seek a reduced sentence. ${ }^{12}$ Moreover, the court may not heed the prosecutor's appeal for lenient treatment of the accused.13 A defendant who, in return for the prosecutor's promise of a reduced sentence, pleads guilty to a felony indictment forecloses the chance of having the charge against him decreased to a misdemeanor; as a convicted felon, he incurs civil disabilities ${ }^{14}$ and increases the likelihood of being subjected to future punishment under multiple offender statutes. ${ }^{15}$ A defendant pleading guilty to a lesser offense does not bear the risk of a future change of heart by the prosecutor; the major obstacle he faces is the court's refusal to allow such a plea after the plea of not guilty to the original indictment. ${ }^{16}$

\section{The Guilty Plea and the Court}

The concessions accorded by prosecutors to a defendant who pleads guilty are not the only sentencing advantages he may expect to receive. A Questionnaire sent by the Yale Law Journal to every federal district judge reveals that 66 per cent of the 140 judges replying consider the defendant's plea a relevant factor in local sentencing procedure. ${ }^{17} 87$ per cent of the judges who acknowl-

12. See note 2 supra.

13. See, e.g., Clemons v. United States, 137 F.2d 302, 305 (4th Cir. 1943) ; People v. Hancasky, 410 Ill. 148, 101 N.E.2d 575 (1951); Maxwell v. State, 292 P.2d 181, 184 (Okla. Crim. App. 1956).

14. One convicted of a felony may not be able to vote, serve on a jury, engage in professions such as medicine or law or hold a civil service job with the federal government. Note, 37 VA. L. Rev. 105, 110-11 (1951); see, e.g., Onio Rev. Code ANN. $\$ 2961.01$ (Supp. 1956); State e.t rel. Att'y General v. Irby, 190 Ark. 786, 81 S.W.2d 419, cert. denied, 296 U.S. 616 (1935).

15. Multiple offender statutes designate increased punishment for defendants already convicted of a given number of felonies. These laws exist in one form or another in most American jurisdictions. Note, Court Treatment of General Recidivist Statutes, 48 Colum. L. Rev. 238, 239 (1948). See, e.g., IрAно CoDE $\$ 19-2514$ (Supp. 1955) (five years to life on the third felony conviction); N.Y. PENAL LAW $\$ 1942$ (a fifteen year minimum for a fourth felony); CODE of VA. ANN. $\$ 53-296$ (Supp. 1956) (unlimited additional imprisonment on third felony conviction).

Habitual offenders' statutes have frequently been attacked on the constitutional basis of double jeopardy for the former offense. But this argument is countered with the contention that the prior criminal acts are not being penalized again but rather that their commission represents an aggravating circumstance of the last crime. Note, 48 Colvus. L. REv. 238, 241 (1948) (citing cases).

16. Courts have discretion to forbid the defendant from changing his plea of not guilty to guilty. Matz v. People, 291 P.2d 1059 (Colo. 1956) (plea of not guilty could not be withdrawn); Commonwealth v. Giacomazza, 311 Mass. 456, 466, 42 N.E.2d 506, 512 (1942) ; People v. Banning, 329 Mich. 1, 6-7, 44 N.W.2d 841, 844 (1950); see Fet. R. Crim. P. 11. But see Ex parte Mougell, 96 Okla. Crim. 354, 355, 255 P.2d 297, 298 (1953).

17. A Yale Laze Journal Questionnaire (hereinafter cited as QUESTIONNAIRE) was sent to all 240 federal district judges. 143 of these Questionnaires were returned but 3 were left unanswered. The returned Questionnaires are on file in the Yale Law Library.

There were 93 affirmative answers to the following question:

"When there is no mandatory sentence for the crime or the particular criminal, and the court has authority to vary the sentence, is it accepted practice to take into 
edged that the plea was germane indicated that a defendant pleading guilty to a crime was given a more lenient punishment than a defendant who pleaded not guilty. ${ }^{18}$ The estimates of the extent to which the fine or prison term was diminished for a defendant pleading guilty varied from 10 to 95 per cent of the punishment which would ordinarily be given after trial and conviction. ${ }^{19}$ Moreover, 56 per cent of the judges who answered the Questionnaire indicated that attorneys for the accused, when arguing prior to sentencing, stressed the fact that their clients had pleaded guilty. ${ }^{20}$

The tendency of courts to award less severe punishment following guilty pleas introduces the possibility of a defendant's obtaining dual sentencing

consideration the fact that the person to be sentenced pleaded guilty, rather than not guilty?"

Considerable regional variations were disclosed. The regions in the following breakdown are adopted from the Colusisia Encyc. 2039 (2d ed. 1950). The following analysis gives the number of judges replying from each region together with the percentage of them who considered the plea a factor in sentencing: New England: 4; 75\%; Middle Atlantic: 30 ; 90\% ; Southeastern: 18 ; 33\%; South : 12 ; 58\%; Great Lakes : 22; 73\%; Trans-Mississippi West: 9 ; 67\%; Great Plains and Western Mountains: 13 ; 31\%; Northwest: $20 ; 70 \%$; Territories and District of Columbia: $12 ; 83 \%$.

Though the Yale Law Journal did not attempt a complete poll of state judges, it sent the Questionnaire to the 20 Superior Court judges in Connecticut. Of the 9 responses received, $\mathrm{S}$ judges indicated that the plea was considered a relevant factor in sentencing in the Superior Courts. The results of this survey are hereinafter referred to as State Questionnaire.

18. There were 81 affirmative responses to the following question:

'If the answer to [the question printed in note 17 supra] is 'Yes,' is it accepted practice to give less severe sentences if the person pleaded guilty, rather than not guilty?"

All 8 judges who indicated on the State Questionnaire that the plea was relevant in determining sentence answered "Yes," to the above question.

19. Most judges who indicated that the punishment was reduced following a guilty plea did not answer the following question:

"If your answer to [the question printed in note 18 supra] is 'Yes,' by what percentage do you estimate that the fine or prison term is usually diminished?"

A few judges stated that the weight given a guilty plea varied from case to case. Others asserted that meaningful estimate of the reduction in sentence attributable to the plea was impossible because of the intermingling of the plea with other factors.

The following percentages were supplied by the judges who answered the above question : one $10 \%$; five $20 \%$; six $25 \%$; one $30 \%$; three $331 / 3 \%$; one $331 / 3-50 \%$; three $50 \%$; one $75 \%$; one $80 \%$; two $90 \%$; one $95 \%$. See Questionnarres.

20. There were 78 affirmative replies to the following question:

"Is it the practice of attorneys for an accused person, when arguing prior to sentencing, to stress the fact that their client has pleaded guilty?"

In addition to the unqualified affirmative answers a few judges replied that while attorneys did not commonly stress the guilty plea, on occasion they might do so.

Rarely, however, does the district attorney point to a defendant's unwillingness to plead guilty as a reason for the imposition of a severe sentence. There were only 30 affirmative replies to the following question:

"Is it the practice of the district attorney at the pre-sentence hearing to stress 
advantages. As already indicated, a prosecutor will frequently allow an accused to plead guilty to an offense punishable by a lower maximum sentence than that provided for the crime initially charged. ${ }^{21}$ Such a defendant may parlay this concession by enjoying the benefit of a lenient judicial sentence for the crime to which he has actually pleaded guilty. For the results of the Questionmaire indicate that judges who give reduced sentences following guilty pleas do not take into consideration whether the defendant was originally indicted for a more serious crime. ${ }^{22}$ This combination of advantages accorded by prosecutors and judges results in a paradox: a defendant originally indicted for the more serious of two related crimes may, by obtaining the dual benefits of a guilty plea, incur less severe punishment than a defendant indicted only for the less serious offense and proven guilty at trial.

The inclination of courts to reduce sentence for defendants pleading guilty is an additional factor influencing the relative advantages to the accused of the two methods of compromise with the prosecutor. A defendant pleading guilty to the initial indictment in return for the prosecutor's promise to seek a more lenient sentence may receive little benefit from this form of bargain.

the fact that the convicted person pleaded not guilty and was found guilty by a jury?"

Some judges who said that the district attorney did not stress the plea indicated that he did not even appear at the hearing.

It should be noted that a court's discretion to determine punishment following a conviction may be limited by the indeterminate sentence laws existing in most jurisdictions. See, generally, Note, 50 HARv. L. REv. 677 (1937). Yet, even under indeterminate sentence laws the court will frequently have authority to establish minimum and maximum periods of imprisonment. E.g., Il. Ans. Star. c. 38, $\$ \$ 801,802$ (Supp. 1955) ; PA. Stat. ANN. tit. 19, \& 1057 (Supp. 1955).

Another limit on judicial sentencing discretion in some states is that under certain circumstances the jury determines the punishment. See REv. ConE Mont. ANN. \$ 94-7411 (Supp. 1955) ; Orla. Stat. AwN. tit. 22, § 926 (Supp. 1955). But see, e.g., Canon v. State, 296 P.2d 202 (Okla. Crim. App. 1956) (court must set punishment if accused pleads guilty) ; Baker v. State, 295 P.2d 294 (Okla. Crim App. 1956) (same).

Another check on judicial sentencing discretion is that some states establish a fixed punishment for certain offenses. See, e.g., N.J. Star. ANN. tit. 2A, \& 113-4 (Supp. 1955) (death for murder in the first degree unless the jury recommends life imprisonment).

21. See note 11 supra and accompanying text.

22. The following question was asked on $66 \%$ of the Questionnaires:

"In determining sentence, is it accepted practice to give a greater punishment to a defendant who, with the prosecutor's permission, has pleaded guilty to a lesser offense than charged in the initial indictment, than to a defendant who has pleaded guilty to the same lesser offense but who was not originally indicted for a more serious crime?"

82 Questionnaires were returned on which this question had been asked. Of the 62 answers provided, 7 were "Yes," and 55 "No." On the State Questionnaire 2 judges answered "Yes," and 5 "No."

While the practice of allowing pleas to a lesser offense is apparently not prevalent in the federal courts, see Criminal Docket of the District of Connecticut; QuestronnaIres, frequently one or more counts will be dropped so that the effect of a lesser plea can be achieved. See note 11 supra. 
Since a judge will probably reduce sentence following a guilty plea even in the absence of an appeal for mercy, not only may such a request be superfluous, ${ }^{23}$ but also the prosecutor may fail to honor his promise to seek lenient treatment. Therefore, to obtain the maximum advantage from his guilty plea, a defendant may be well-advised to seek some down-grading of the charges against him. ${ }^{24}$ Such a conclusion is especially true in view of the tendency of judges to disregard the original indictment when sentencing an accused. ${ }^{25}$

\section{The Guilty Plea v. The Trial: Rationales for Adjustring SENTENCE}

The reasons why courts feel the defendant's plea is a relevant factor in sentencing may be separated into two major categories. In their answers to the Questionnaire many judges expressed the belief that an accused pleading guilty was generally less culpable, and thus less in need of punishment, than a defendant convicted after trial. In addition, the view was asserted that a defendant pleading guilty was entitled to some discount in punishment because of the aid of his plea in the efficient administration of justice. Several judges emphasized that the plea was only one of numerous factors taken into consideration in determining sentence, and that the weight given the plea varied from case to case. ${ }^{26}$

\section{The Guilty Plea as Evidence of Repentance}

The predominant basis for a court's considering a defendant pleading guilty less culpable than one denying guilt is the belief that a guilty plea demonstrates the readiness of the accused to accept responsibility for his criminal acts. ${ }^{27}$ Judges feel that such a confession of wrongdoing evinces a repentant attitude,

23. Although a few judges indicated that they may be swayed by the prosecutor's recommendation, the overwhelming majority of those reducing sentence following a guilty plea gave reasons indicating that they were unaffected by the prosecutor's infuence. It is said, however, that normally the court will follow the prosecutor's recommendation. Clemons v. United States, 137 F.2d 302, 305 (4th Cir. 1943).

24. Alternatively, he should attempt to obtain the prosecutor's recommendation for probation since this might have considerable weight with the court. See Newman, supra note 4, at 789. But see note 23 supra.

Federal courts may grant probation in any case except when the offense is punishable by death or life imprisonment. 18 U.S.C. $\$ 3651$ (1952). Similar discretion has been given state courts. E.g., Del. Cone ANn. tit. 11, \& 4321 (Supp. 1954); N.H. Rev. Stat. ANN. § 504.1 (Supp. 1955).

25. See note 22 supra and accompanying text.

26. "Each case presents a different problem to the sentencing court; age, background, nature of offense, prospects for rehabilitation, etc. all enter into the court's thinking." QUESTIONNAIRE.

27. 46 replies expressed this basic thought in one way or another. See also King, Criminal Procedure from the Viewpoint of the Trial Judge, 25 CoNN. B.J. 202, 204-05 (1951). 
and thus represents an important step toward rehabilitation of the accused.28 A few judges added the qualification that a guilty plea would not be considered evidence of reformation unless the accused had no prior criminal record.

A reduction in sentence following a guilty plea is consistent with the rehabilitation theory of criminal punishment ${ }^{29}$ only if such a plea is indicative of remorse for prior criminal acts. Although a guilty plea may at times be motivated by repentance, more often it would seem to represent exploitation by the accused of the prosecutor's and court's reaction to such a plea. ${ }^{30}$ If a defendant who acknowledged his guilt were aware that the plea could not influence the extent of punishment, then perhaps his action might reflect a renunciation of criminal propensities. But the very fact that a defendant realizes a guilty plea may mitigate punishment impairs the value of the plea as a gauge of character. Faced with convincing evidence of guilt, an accused

28. E.g.,

"A plea of guilty frequently is an expression of contrition and repentance on the part of the defendant and is an indication of a purpose of amendment and reformation."

"His willingness to admit guilt usually indicates a degree of repentance which should be considered ...."

"[The defendant is] more inclined to face his situation realistically and maturely and thus less likely to repeat the offense or to commit others."

QUeSTIONNAIRES.

29. The purpose of the criminal law has been said to be to "protect socicty against crime." Chandler, Latter-Day Procedures in the Sentencing and Treatment of Offenders in the Federal Courts, 37 VA. L. REv. 825, 828 (1951). This protection may be effected by deterring potential criminal offenders and/or by rehabilitating individuals convicted of criminal conduct. Ibid. Since the sentencing trend is toward "individualization," "treatment" and punishment to fit the criminal rather than the crime, reformation appears to be the more popular doctrine. See Hyde, Individualization in Criminal Panishment, 31 Iowa L. REv. 200 (1946) ; Yankwich, The Federal Penal System, 10 F.R.D. 539, 542 (1951). Reformation would protect society by teaching the offender not to repeat his criminal ways. This theory has been recognized as a prime goal of the sentencing function in numerous cases. E.g., Williams v. New York, 337 U.S. 241, 248 (1949); France v. State, 95 Okla. Crim. 244, 246, 244 P.2d 341, 343 (1952). For an explanation of deterrence see note 33 infra.

The retribution doctrine of criminal sentencing would punish the defendant in vengeance for his actions. Although retribution has fallen into disrepute as a theory of punishment, see Chandler, supra at 828 , there are still cases relying in part on this rationale. E.g.. State v. Meyer, 163 Ohio St. 279, 287, 126 N.E.2d 585, 589 (1955) ; Larkey v. State, 95 Okla. Crim. 338, 342, 245 P.2d 751, 755 (1952); see also Comment, 65 Yale L.J. 209, 224-29 (1955).

30. See Dash, Cracks in the Foundation of Criminal Justice, 46 ILL. L. REv. 385, 395-97 (1951) ; Newman, Pleading Guilty for Considerations: A Study of Bargain Justice, 46 J. Crins. L., C. \& P.S. 780, 783-84 (1956); see also Moley, Poumtrcs and Crmirnal Prosecutron 166-67 (1929) ; cf. Ward v. United States, 116 F.2d 135 (6th Cir. 1940) (defendant desired to withdraw plea of guilty when his "compromise" seemed dishonored); People v. King, 1 Ill. 2d 496, 116 N.E.2d 623 (1953) (same); Clark \& Shuldan, A Study of LAW AdMinistration iN ConNecticur 188 (1937) (many defendants who ultimately pleaded guilty originally had pleaded not guilty). 
will probably enter a guilty plea for reasons of expediency, not principle. ${ }^{31}$ Moreover, while recidivists, poor prospects for reformation, will not be deterred from admitting guilt by the fear of impeaching their communal reputations, first offenders, though truly repentant, may well deny guilt in a desperate effort to avoid the stigma of conviction. ${ }^{32}$

Nor can lenient treatment of defendants pleading guilty be justified in terms of a deterrence theory of criminal punishment. ${ }^{38}$ It seems evident that the goal of discouraging future criminal activity by punishing past offenders is not served by awarding a reduced sentence to a person willing to admit his crime. Indeed, the awareness that a guilty plea will probably result in clemency may seriously undercut the deterrent effect of criminal prosecutions. ${ }^{34}$

\section{Commission of Perjury at Trial}

A second reason why judges award a defendant convicted at trial a more severe sentence than one pleading guilty is the belief that the former has usually committed perjury in his defense. ${ }^{35}$ Of course this inference is drawn

31. Cf. Newman, supra note 30 , at 783-84:

"The recidivists were both conviction wise and conviction susceptible in the dual sense that they knew of the possibility of bargaining a guilty plea for a light sentence and at the same time were vulnerable, because of their records, to threats of the prosecutor to 'throw the book' at them unless they confessed."

32. In addition to suffering legal disabilities, see note 14 supra, a person convicted of a crime is informally punished by the community at large. For example, a released convict may have difficulty securing employment. PrIson Ass'n of N.Y. ANN. ReP. 60 (1950).

In some cases first offenders may be hardened criminals who had been shrewd enough to avoid apprehension. Such defendants may not be repentant of their criminal conduct but rather may be contemplating return to a life of crime. Peterson, Rights and Needs of the Criminal, 31 IowA L. REv. 213, 217 (1946).

33. The theory of punishment as a deterrent is that the example of the defendant's fate will serve to make others fearful of the consequences of criminal conduct. Tuohy, Prosecution and Punishment for Crime, 31 Iowa L. Rev. 205-06 (1946); see Law v. State, 238 Ala. 428, 191 So. 803 (1939) (dictum); Frazier v. Commonwealth, $291 \mathrm{Ky}$. 467, 165 S.W.2d 33 (1942); State ex rel. Williams v. Riffe, 127 W. Va. 573, 34 S.E.2d 21 (1945).

34. Dash, supra note 30 , at 395-97.

35. 29 judges indicated that perjury was relied on as a basis for more severe punishment of a defendant convicted at trial. The following statements are typical:

"The only factor which militates against a defendant appearing for sentence after trial is the conviction which the court sometimes obtains from a trial that the defendant has compounded his offense with perjury."

"Where a defendant takes the stand and patently commits perjury it usually demonstrates that more severe corrective measures are necessary and this could reflect itself in a longer sentence."

"When an accused stands trial, testifies in his own behalf and in the opinion of the trial judge commits perjury, that is taken into account at the time of sentence and the sentence is then more severe than if he had pled guilty."

QuestionNAiRES. 
only when the defendant has taken the stand. ${ }^{36}$ While some judges indicated that an implied finding of perjury is predicated upon a review of the facts and circumstances of each case, other judges appear to presume the occurence of perjury from the mere fact of conviction. ${ }^{37}$ Regardless of the chain of reasoning employed, judges agreed that a defendant who was also a perjurer deserved additional punishment.

The perjury rationale for increasing sentence may be viewed from two different perspectives. It may be said that the judge is awarding the defendant a given punishment for the crime of which he has been convicted, and then, within the limits of his discretion to fix punishment for this offense, is imposing an additional sentence because the defendant has committed the second crime of perjury. ${ }^{38}$ Or the court may be said to consider the occurrence of perjury as a culpable act bearing upon the character of the accused; accordingly, the defendant is given a longer sentence for the crime of which he stands convicted because his perjurious conduct increases the difficulty of reformation. ${ }^{3 a}$ Both of these justifications seem unsound.

Penalizing the defendant for the substantive crime of perjury by increasing the sentence for another offense contradicts basic tenets of criminal law. Since perjury is properly punishable in a separate criminal proceeding, ${ }^{40}$ a summary

36. Because of the privilege against self-incrimination the defendant cannot be compelled to testify. See U.S. Const. amend. V; see also, e.g., MIss. Const. art. 3, $\$ 26$; N.H. Const. pt. 1 , art. 15 ; Ore. Const. art. $1, \S 12$.

Although defendants sometimes refuse to testify, e.g., United States v. Hamilton, 97 F. Supp. 123 (S.D.W. Va. 1951), such cases are rare since a defendant who does not take the stand will probably fatally prejudice his chances of acquittal. See note 90 infra.

37. See Question NaIRES.

38. See Peterson v. United States, 246 Fed. 118 (4th Cir. 1917), cert. denicd, 246 U.S. 661 (1918).

39. See Humes v. United States, 186 F.2d 875 (10th Cir. 1951); Peterson v. United States, supra note 38.

In judging the defendant's prospects for reformation, courts consider other crimes although they are not always evidenced by convictions. Schwellenbach, Information vs. Intuition in the Imposition of Sentence, 27 J. AM. Jup. Soc'y 52 (1943) ; Note, 101 U. P.1. L. REv. 257, 261-62, 270 (1952); see Chandler, Latter-Day Procedures in the Sentencing and Treatment of Offenders in the Federal Courts, 37 VA. L. REv. 825, 830-35 (1951). Statutes establish procedures for courts to obtain information about a convicted defendant's past activity. E.g., Fed. R. Crim. P. 32(c); Ind. Stat. ANN. \$\$ 9-2213-14 (1956); LA. REv. STar. tit. 15, $\S 531$ (Supp. 1955). For a description of the procedure used in presentence reports see Fra. Parole Comm'n AnN. Rep. 2-3 (1943).

40. The perjury statutes do not exclude a defendant's perjury in his own behalf. See, e.g., 18 U.S.C. $\S 1621$ (1952) ; DeL. Code ANN. tit. 11, \$\$ 721-22 (Supp. 1954) ; Rev. Star. Me. c. 135, \& 1-4 (Supp. 1954). It will not violate double jeopardy limitations to prosecute a defendant for perjury committed in his own behalf. United States v. Williams, 341 U.S. 58 (1951).

However defendants are rarely prosecuted for the commission of perjury at a trial terminating in their conviction. But see ibid. Cases in which defendants acquitted in a criminal action are later prosecuted for perjury are probably much more common. E.g., ibid.; United States v. Slutzky, 79 F.2d 504 (3d Cir. 1935); State v. Vandemark, 77 Conn. 201, 58 Atl. 715 (1904). 
adjudication by the court of the defendant's guilt is an inadequate substitute for the constitutional safeguards inherent in a new indictment and jury trial.41 Moreover, even though the defendant's conviction must be taken as a repudiation of his testimony, the judgment in the initial case would undoubtedly be inadmissible evidence in a subsequent perjury proceeding. ${ }^{42}$ In light of this doctrine, the practice of conclusively presuming the commission of perjury from the fact of conviction is particularly suspect. ${ }^{43}$

A defendant is not always entitled to a separate jury trial on the issue of perjury; lying under oath in a judicial proceeding may at times be punishable as criminal contempt. ${ }^{44}$ Under rule 42 (a) of the Federal Rules of Criminal Procedure, criminal contempt may be punished summarily if the judge certifies that the conduct constituting the contempt was committed in the presence of the court. ${ }^{45}$ However, the Supreme Court has held that perjury standing alone does not "obstruct the administration of justice" and hence does not by itself constitute criminal contempt under the applicable federal statute. ${ }^{46}$ To be punishable, the perjury must be such that it blocks the performance of

41. Since perjury is a substantive crime, see statutes cited in note 40 supra, in prosecutions for perjury the defendant must be accorded full constitutional guarantees.

42. Wharton, Evidence in Criainal Issues $\$ 602$ (a) (8th ed. 1880); see Starnes v. State, 125 Tex. Crim. 21, 66 S.W.2d 335 (1933); see also United States v. Burkhardt, 31 Fed. 141 (C.C. Ore. 1887) ; Spearman v. State, 68 Tex. Crim. 449, 152 S.W. 915 (1913).

The judgment roll in a civil case is inadmissible in a subsequent perjury prosecution as evidence of the commission of perjury at the first trial. Wharton, Criminal Evidence $\$ 639$ (12th ed. 1955) (collecting cases). The judgment roll will be admissible to show the occurrence of the proceeding, the jurisdiction of the court, the giving of testimony and its materiality. People v. Reitz, 86 Cal. App. 791, 796, 261 Pac. 526, 528 (1927). When the judgment roll is admitted for these limited purposes, the findings and decrees are cxcluded. See State v. King, 165 Ore. 26, 37, 103 P.2d 751, 755-56 (1940).

43. A former conviction would not collaterally estop a defendant in a prosecution for perjury from denying that he had sworn falsely at the first trial. Developments in the Lazw-Res Judicata, 65 HaRv. L. Rev. 818, 877 n.441 (1952).

44. See, generally, Comment, 65 YaLE L.J. 846, 848-51 (1956); Note, Falsification as Contempt, 7 VAND. L. Rev. 272 (1954).

Some false testimony which might not be punishable as a substantive crime of perjury can be punished as contempt because in some respects the requirements of perjury are more difficult to satisfy. The principal distinction appears to be that whereas any false swearing may qualify as contempt, perjury is committed only if the lie was material. $I d$. at 273, 280. But see United States v. Talbot, 133 F. Supp. 120, 128 (D. Alaska 1955) (defendant acquitted of criminal contempt, the court holding, inter alia, that the testimony was not material); People v. Williams, 348 I1l. App. 224, 108 N.E.2d 736 (1952). Testimony is material if it could have influenced the tribunal in determining the issues before it. Fraser v. United States, 145 F.2d 145 (6th Cir. 1944), cert. denied, 324 U.S. 842 (1945) ; United States v. Icardi, 140 F. Supp. 383 (D.D.C. 1956) ; People v. Sagehorn, 140 Adv. Cal. App. 2d 134, 143, 294 P.2d 1062, 1069 (1956).

45. "A criminal contempt may be punished summarily if the judge certifies that he saw or heard the conduct constituting the contempt and that it was committed in the actual presence of the court." FED. R. CRIM. P. 42(a).

46. In re Michael, 326 U.S. 224 (1945); Ex parte Hudgings, 249 U.S. 378 (1919).

1s U.S.C. $\$ 401$ (1952) provides: 
judicial duty. ${ }^{47}$ Although the application of this doctrine has evoked considerable confusion, ${ }^{48}$ it is questionable whether the requisite obstruction of justice could be said to occur when the defendant has been convicted in spite of his perjured testimony. ${ }^{49}$ In addition, cases have indicated that the bona fide belief of a presiding judge that a witness has committed perjury does not by itself justify summary punishment of the contemnor without due notice and hearing. ${ }^{\text {to }}$

When a judge increases the sentence awarded for the charged crime as a penalty for perjury not summarily punishable as contempt, he utilizes his discretion to accomplish a result he could not have effected directly. The rigid requirements which must be met for perjury to qualify as criminal contempt reflect the policy that the contempt power should be strictly applied, ${ }^{51}$ since the contemnor is sentenced without the normal safeguards of procedural due process. ${ }^{52}$ Such a policy is jeopardized when a judge increases sentence for another crime to discipline a defendant whose perjured testimony, though not qualifying as contempt, has been felt to offend the dignity of the court.

Assuming that the perjury of the accused would be subject to punishment as criminal contempt, the court that awards a more severe sentence on the basis of the defendant's commission of perjury may be said to substitute one form of summary punishment for another concededly within its power. At first glance, such a practice does not seem objectionable. However, it should

"A court of the United States shall have power to punish by fine or imprisonment, at its discretion, such contempt of its authority, and none other, as-

"(1) Misbehavior of any person in its presence or so near thereto as to obstruct the administration of justice;

"(2) ...;

"(3) ...."

47. "The [federal] courts say there must be 'defiance of the court' or a 'blocking of the inquiry." " Comment, 65 Y ALE L.J. 846, 849 (1956).

48. There have been several reversals in the federal courts because of misapplication of "obstruction" principles. Ibid.

In addition, reversals for erroneous application of false swearing contempt standards in the state courts are frequent. E.g., People v. Harrison, 403 Ill. 320, 86 N.E.2d 208 (1949); In re Scott, 342 Mich. 614, 71 N.W.2d 71 (1955); Fawick Airflex Co. v. Local 735, United Electrical Workers, CIO, 87 Ohio App. 371, 92 N.E.2d 436, appeals dismissed, 153 Ohio St. 589, 92 N.E.2d 689, 154 Ohio St. 106, 93 N.E.2d 409, 154 Ohio St. 205, 93 N.E.2d 769 (1950).

Punishment of perjury as contempt appears to be a highly disfavored remedy. See ibid. Restrictions on the broad use of the contempt power have been urged in order that witnesses may not be discouraged from testifying. Nelles, The Summary Pozver to Punish for Contempt, 31 Colum. L. Rev. 956, 969-70 (1931).

49. Cf. In re Michael, 326 U.S. 224 (1945).

50. State courts add the requirement that the court have "judicial knowledge" that the testimony was in fact false. Judicial knowledge may be said to exist, for example, when testimony conflicts with uncontrovertible documentary evidence. Note, 7 VAND. L. Rev. 272, 278-79 \& n.55 (1954) (collecting cases). See also In re Oliver, 333 U.S. 257, 275-76 (1948) ; Annot., 93 L. Ed. 578, 583-84 (1950).

51. Nelles, supra note 48, at 969-70; Comment, 65 YALE L.J. 846, 850-51 (1956); Note, 7 VAND. L. Rev. 272, 273-74 (1954).

52. In re Murchison, 349 U.S. 133 (1955); In re Oliver, 333 U.S. 257, 273-78 (1948). 
be noted that a sentence within the legal limits provided for the proven crime is not usually subject to appellate review. ${ }^{53}$ Accordingly, a defendant whose sentence has been increased as a penalty for perjury felt to constitute contempt is denied the right of appeal which he would have enjoyed if the court had followed the standard procedure for summary punishment of contempt. ${ }^{54}$ Such a deprivation is particularly significant in view of the frequent misapplication by trial courts of the standards for punishing perjury as criminal contempt.55

Punishment of a defendant's commission of perjury by augmenting sentence for another crime denies him constitutional and statutory safeguards which he would enjoy if a separate criminal proceeding or the criminal contempt procedure were employed. ${ }^{56}$ Yet when a judge, in the exercise of his discretion, imposes a more severe sentence on the basis of perjured testimony, it may be contended that he is not punishing perjury as such, but is merely considering the occurrence of perjury as an indication of the defendant's prospects for reformation. In determining sentence, a judge may constitutionally take cognizance of a wide variety of information bearing upon the character and background of the convicted defendant. In Williams $v$. New York, ${ }^{57}$ the Supreme Court held that a statute ${ }^{58}$ which authorized submission to a judge of a pre-

53. " $[I] \mathrm{n}$ the absence of a specific statutory grant of power an appellate court will not reduce a sentence which is within statutory limits merely because it is, in the judgment of that court, excessive." Hall, Reduction of Criminal Sentences on Appeal: I, 37 CoLuM. L. REv. 521, 522 (1937).

Accordingly federal appellate courts hold that they have no power to reduce a sentence legally imposed within statutory limits. E.g., Brown v. United States, 222 F.2d 293, 298-99 (9th Cir. 1955); Gurera v. United States, 40 F.2d 338 (8th Cir. 1930). However at one time the courts exercised such a power, based on statutory authority. See United States v. Wynn, 11 Fed. 57 (C.C.E.D. Mo. 1882) ; Bates v. United States, 10 Fed. 92, 96 (C.C.N.D. Ill. 1881) ; see also Freeman v. United States, 243 Fed. 353, 357 (9th Cir. 1917), cert. denied, 249 U.S. 600 (1918). The question should not be treated as foreclosed because in Kawakita v. United States, 343 U.S. 717, 745 (1952), the Supreme Court, when faced with the argument that under the circumstances the death penalty for treason was unreasonable, did not disclaim appellate power to reduce sentence but instead ruled that the punishment was reasonable. But see Blockburger v. United States, 284 U.S. 299, 305 (1932).

In some states appellate power to revise legal sentences is found, although frequently the reviewing court insists upon a showing of abuse of discretion by the trial court. See, c.g., State v. Telavera, 76 Ariz. 183, 186, 261 P.2d 997, 1000 (1953) ; State v. Constanzo, 76 Idaho 19, 27, 276 P.2d 959, 963 (1954); Commonwealth v. Edwards, 380 Pa. 52, 110 A.2d 216 (1955); see also Sobeloff, $A$ Recommendation for Appellate Review of Criminal Sentences, 21 Brooklyn L. Rev. 2 (1954).

54. An order adjudging a defendant guilty of criminal contempt is appealable. In re Merchants' Stock and Grain Co., 223 U.S. 639, 642 (1912); In re Manufacturers Trading Corp., 194 F.2d 948, 955 (6th Cir. 1952) (dictum).

55. See note 48 supra.

56. See text at notes 45-50 supra.

57. 337 U.S. 241 (1949).

58. N.Y. CRIMr. CODE $§ 482$ :

"Before ... sentence the court shall cause the defendant's previous criminal record to be submitted to it, including any reports that may have been made as a 
sentencing report describing the past life, habits and mental and moral propensities of the accused was not offensive to due process, though the defendant had no right to confront and cross-examine the investigators who compiled the report. ${ }^{59}$ The bona fide belief of a trial judge that a defendant has committed perjury would seem as reliable a source of information as the data permitted under the Williams doctrine. ${ }^{60}$ But, even though the judge's belief that perjury has occurred may constitutionally influence his judgment of the accused's character, the question remains whether the commission of perjury demonstrates a greater need for rehabilitation.

The prior criminal conduct of a defendant awaiting sentence is acknowledged to be a gauge of his antisocial propensities, and hence useful in predicting the sentence necessary to effect reformation. ${ }^{01}$ Accordingly judges consider, in addition to convictions, other purported illegal activities of the accused as revealed by pre-sentencing reports or other sources of information. ${ }^{\text {t2 }}$ Viewed from this perspective, perjury apparently committed at trial may be classified an illegal activity properly incorporated into the defendant's criminal record. And, since past criminal behavior is a factor influencing length of sentence, a pro tanto increase in the punishment accorded a defendant suspected of perjury may at first glance seem defensible. ${ }^{63}$

However, when a judge awards a defendant believed to be a perjurer a more severe sentence than he would have given a defendant pleading guilty to the same offense but otherwise possessing an identical criminal record, such a dis-

result of a mental, phychiatric [sic] or physical examination of such person, and may seek any information that will aid the court in determining the proper treatment of such defendant." (Emphasis added.)

See also note 39 supra.

59. 337 U.S. at 245.

60. Williams $v$. Neze York does not hold that due process is inapplicable in sentencing. Rather it holds that in the light of modern penological concepts the New York presentencing procedure is reasonable. Id. at 252 n.18. See Townsend v. Burke, 334 U.S. 736 (1948). Under Townsent the sentencing court must not base its decision on information "extensively and materially false" which the defendant cannot refute. Id. at 741 ; see Smith v. United States, 223 F.2d 750 (5th Cir. 1955); see, generally. Note, 101 U. PA. L. REv. 257, 263-71 (1952).

61. Williams v. New York, 337 U.S. 241 (1949) ; State v. Owen, 73 Idaho 394, 402, 253 P.2d 203, 207 (1953); see note 39 supra and accompanying text.

62. See Pence v. United States, 219 F.2d 70 (10th Cir. 1955); People v. Rummerfield, 4 Ill. 2d 29, 122 N.E.2d 170 (1954); Driver v. State, 201 Md. 25, 92 A.2d 5711 (1952). However the court may, in the exercise of its discretion, dispense with the presentence report. United States v. Schwenke, 221 F.2d 356 (2d Cir. 1955). But sec State v. Culver, 40 N.J. Super. 427,123 A.2d 383 (App. Div. 1956) (dictum).

63. It should be noted, however, that in the federal courts the defendant as a matter of right can insist that the pre-sentence report be disclosed and hence can refute inarcuracies. Smith v. United States, 223 F.2d 750 (5th Cir. 1955). Contra, State v. Moore, 108 A.2d 675 (Del. Super. Ct. 1954) (state practice). In contrast if a seintence is increased because of supposed perjury, the defendant may never know the reason for his additional punishment since no explanation need be given. 
crimination is justified only if the perjury indicates a distinction in the character of the two defendants. An individual willing to commit a crime would quite likely have no moral scruples against subsequently denying under oath its commission in order to escape punishment. In the usual case, a defendant is motivated to admit guilt not by an aversion to perjury but by the realization that his plea may be effective in -mitigating sentence. ${ }^{64}$ For an accused confronted with incriminating evidence, a guilty plea may appear to be a far more profitable choice than an ineffective false denial at trial. When perjury is avoided for reasons of expediency, not principle, it is debatable whether the defendant pleading guilty is a better prospect for reformation than one who perjures himself at trial in an unsuccessful effort to obtain acquittal. On the other hand, the defendant whose sentence has been increased on the basis of suspected perjury has, in the opinion of the court, actually perjured himself; his counterpart who pleaded guilty may have entertained the propensity to commit perjury, but did not in fact do so. Thus in evaluating the character of the two defendants, it may sometimes be reasonable to give greater weight to the commission of perjury than to the mere propensity to commit perjury. ${ }^{65}$

In the case of a first offender, it would seem unreasonable to presume a greater need for reformation solely -because the accused has given perjured testimony in his defense. ${ }^{68}$ Such false swearing, rather than demonstrative of future criminal propensities, may be prompted by an ardent desire to avoid the loss of community standing accompanying an initial conviction. ${ }^{67}$ Thus the defendant may still be an excellent prospect for rehabilitation, despite his conduct at trial.

\section{Assertion of Frivolous Defense}

Some judges reported that a defendant pleading not guilty was awarded a more severe sentence than a defendant pleading guilty only if the court felt that the demand for trial was not made in good faith but was essentially a

64. See Newman, Pleading Guilty for Considerations: A Study of Bargain Justice, 46 J. CRIM. L., C. \& P.S. 780, 783-84 (1956); see also In re Smith, 162 Ohio St. 58, 120 N.E.2d 736 (1954) ; Maxwell v. State, 292 P.2d 181 (Okla. Crim. App. 1956) ; Commonwealth v. Cole, 384 Pa. 40, 119 A.2d 253 (1956) ; Hobson v. Youell, 177 Va. 906, 914-15, 15 S.E.2d 76,79 (1941).

65. Criminal intent alone does not constitute a crime; there must be some act accompanying the intent. Mrller, Crminal Law $\$ 14$ (1934); see People v. Jelke, 1 N.Y.2d 321, 330, 135 N.E.2d 213, 218-19 (1956); Commonwealth v. Willard, $179 \mathrm{~Pa}$. Super. 368,116 A.2d 751 (1955). Therefore it may be held consistent with criminal theory to give greater evidentiary weight to an actual act than to a frame of mind when determining the appropriate punishment for another crime. Cf. Williams v. New York, 337 U.S. 241, 244 (1949) (trial court relied on evidence of other crimes but also described defendant as a "'menace to society.' ").

66. First offenders may of course be given more lenient sentences than recidivists. However, the Questionnaires suggest that a first offender who pleads guilty will much more likely be given clemency than one who has been convicted at trial.

67. See note 14 supra; note 32 supra and accompanying text. 
dilatory tactic.68 The view was expressed that a defendant faced with overwhelming evidence of guilt who presented a frivolous defense in a desperate gamble to sway a jury deserved additional punishment. In contrast, an accused whose defense raised a substantial question of law or fact was accorded the same sentencing treatment as was given defendants pleading guilty. Since the Sixth Amendment guarantee of trial by jury does not distinguish between dilatory and substantial defenses, ${ }^{69}$ the defendant whose punishment has been increased for demanding what the court considers a useless trial is in effect being penalized for asserting his constitutional rights. It is questionable whether a not guilty plea can ever be fairly deemed "dilatory," since it accords with the presumption of innocence which the prosecution must rebut beyond a reasonable doubt. ${ }^{70}$ In addition, the judicial determination that a defense was frivolous is made when the accused has already been convicted ; any defense appears less meritorious after it has been rejected. ${ }^{\mathbf{1 1}}$

\section{Revelation of Circumstances of Crime}

Four judges answering the Questionnaire suggested that a guilty plea may contribute to a shorter sentence because the brutal circumstances frequently accompanying criminal activity are not emphasized by the prosecution, and vividly recounted at trial. ${ }^{72}$ Such a position implies that the pre-sentencing report on a defendant pleading guilty either does not describe the details of the crime or lacks the dramatic thrust inherent in testimony. Though judges are naturally swayed by emotional responses, ${ }^{73}$ the means by which a defendant is convicted cannot alter the actual nature of his criminal conduct. Theo-

68. 11 judges gave explanations similar to the ones below:

"[W]e do not penalize the defendant for standing trial if he has a real or reasonable defense-otherwise we do-as a penalty for needlessly taking up time and creating expense."

"No person should ever be given a longer sentence because he insists upon a trial unless it is apparent that he is guilty and is just attempting to win an acquittal at any cost."

QUESTIONNATRES.

69. U.S. Const. amend. VI; see Ex parte Quirin, 317 U.S. 1, 25 (1942). Nor is any distinction made by constitutional provisions existing in all states. See, e.g., Mo. Const. art. I § 18(a); N.C. Const. art. I, § 13; WIs. Const. art. I, § 7.

70. For statements of the presumption of innocence see, e.g., People v. Sobczak, 344 Mich. 465, 73 N.W.2d 921 (1955); State v. Pietranton, 84 S.E.2d 774, 787-89 (W. Va. 1954).

71. See United States v. Konovsky, 202 F.2d 721, 726-27 (7th Cir. 1953).

72. "It must be kept in mind that ordinarily on a plea of guilty the defendant's case is presented in its most favorable light ...."

"When a man pleads guilty all the details of his crime are rarely presented to the judge and a moderate, average sentence is imposed."

QUestTONNAIRES.

73. See Offutt v. United States, 348 U.S. 11, 13-14 (1954); Philadelphia Evening Bulletin, July 10, 1956, p. 1, col. 4 (a judge disqualified himself from a criminal trial because so emotionally involved he "could show no sympathy, no mercy or anything else"). 
retically, the circumstances of the crime should be given the same weight in evaluating the character of the accused regardless of his plea. ${ }^{74}$

\section{Role of the Plea in Efficient Criminal Administration}

Many judges expressed the belief that a defendant pleading guilty should receive some reduction in the gravity of sentence because of the role of guilty pleas in the efficient and economical administration of criminal law. ${ }^{75}$ When a defendant admits the commission of a crime, the government is saved the time and money that a potentially lengthy trial entails. Guilty pleas help keep crowded criminal dockets current and enable other defendants pleading not guilty to obtain speedy trials. ${ }^{70}$ Such reasons for mitigating sentence are predicated upon practical administrative considerations and do not reflect the belief that a defendant who pleads guilty is a better prospect for reformation. ${ }^{77}$

The practice of promoting efficient justice by judicial adjustment of sentences to encourage guilty pleas must be viewed in terms of the court's function in criminal administration. While the prosecutor is charged with the statutory duty of representing the state in criminal proceedings, ${ }^{78}$ the judge is not an advocate. ${ }^{79}$ Vested with discretion to designate punishment for criminal offenders, the judge must exercise his authority impartially, ${ }^{80}$ having "no interest other than the pursuit of justice."81 Modern penal theory holds that the interests of both society and the defendant are served by adjust-

74. Hence even after a plea of guilty the court may attempt to ascertain the circumstances of the crime. See Zeff v. Sanford, 31 F. Supp. 736, 737 (N.D. Ga.), aff'd por curiam, 114 F.2d 1018 (5th Cir. 1940).

75. 34 judges concurred in the sentiments expressed below:

"I make them a concession for pleading guilty for two reasons: (1) it saves the Government a great deal of time and money; (2) I believe it is in the best interests of society that criminal calendars be caught up as closely as possible, and by eliminating a great many trials the other defendants will obtain a more speedy trial."

"The fact that the Government has been saved the expense of trial is considered."

QUESTIONNAIRES.

76. See text at notes 6-8 supra; King, Criminal Procedure From the Vierupoint of the Trial Judge, 25 ConN. B.J. 202, 204-05 (1951); Note, 33 CoRneIr. L.Q. 407, 408-09 (1948).

77. "Though a plea of guilty usually effects a discount because the government has saved costs of trial-it should not in legal theory have this effect. Dollar saving doesn't protect society or rehabilitate, and it leads to a sentence 'bargaining atmosphere." " (Emphasis added.)

QUESTIONNAIRE.

78. See statutes cited in note 6 supra.

79. Adams v. United States ex rel. McCann, 317 U.S. 269, 275 (1942); Wyzanski,

A Trial Judge's Freedom and Responsibility, 65 Harv. L. Rev. 1281, 1291-93 (1952).

80. In re Míurchison, 349 U.S. 133 (1955); Tumey v. Ohio, 273 U.S. 510, 522 (1927).

81. Adams v. United States ex rel. McCann, 317 U.S. 269, 275 (1942). 
ing sentence to reflect the individual's prospects for rehabilitation. ${ }^{82}$ But when defendants guilty of the same crime are awarded different sentences for administrative reasons, such a discrimination cannot be justified in terms of individual culpability. ${ }^{83}$ An accused who receives a harsher punishment than the court would have decreed had he waived a costly and time-consuming trial pays a judicially imposed penalty for exercising constitutionally guaranteed rights. Nor can such an objection be overcome by the rationale that judges, rather than penalizing defendants convicted at trial, instead reward those who plead guilty. ${ }^{84}$ This distinction is illusory; the fact is that, whether by means of forfeiting a reward or incurring a penalty, a demand for trial will result in a more severe punishment than would be imposed following a guilty plea. In view of the concepts of impartiality and fairness which have traditionally guided the exercise of the judicial function, ${ }^{85}$ it is submitted that encouragement of guilty pleas by sentencing concessions is more censurable when practiced by courts than by prosecutors. ${ }^{86}$

\section{Sentencing Policy and the Innocent Defendant}

The greatest danger inherent in the policy of utilizing the plea as a factor in sentencing is that innocent men will be influenced to plead guilty. ${ }^{87}$ Confronted with the probability that conviction after trial will substantially enhance punishment, ${ }^{88}$ a defendant may decide that assertion of his innocence entails too much of a risk. ${ }^{89}$ The greater the potential discrepancy in the sentence to be imposed following trial convictions and guilty pleas, the more will be magnified the fear of standing trial. A defendant may be especially reluctant to plead not guilty when he has a criminal record, for then his chances of successfully establishing innocence are considerably diminished. Under preva-

82. See note 29 supra.

83. Even if the court attempts to fit the punishment to the crime rather than to the individual, see State v. English, 242 Iowa 248, 252, 46 N.W.2d 13, 15 (1951), the administrative convenience rationale is unacceptable because cooperation subsequent to the crime does not alter the criminal act.

84. "A not guilty plea does not induce a more severe sentence. A guilty plea induces a less severe sentence." Questionsaire. See also King, supra note 76, at 204-05.

85. The right of the accused to an impartial judge "is a concept of ancient origin inherent in the common law." Wilson v. State, 222 Ind. 63, 82, 51 N.E.2d 848, 855 (1943): see also notes 79-81 supra and accompanying text.

86. Cf. Donnelly, Unconvicting the Imnocent, 6 VAND. L. Rev. 20, 38 (1952).

87. For a refutation of the assumption that an innocent man will never confess to a crime he has not committed, see 3 Wignore, EvideNce $\$ 822$ (3d ed. 1940); Note, Volumtary False Confessions: A Neglected Area in Crininal Administration, 28 Ind. L.J. 374 passim (1953).

88. See text at notes 17-21 supra.

89. Newman, Pleading Guilty for Considerations: A Study of Bargain Justice, 46 J. CRTM. L., C. \& P.S. 780, 783-84 (1956). This might be particularly true in cases in which the defendant has been accused of a felony but can plead guilty to a misdemeanor. In such a case the defendant can avoid the local habitual offenders' statute. See note 15 supra. 
lent evidentiary rules, the defendant's criminal past may be brought out at trial by one means or another, with consequent prejudice to his defense. ${ }^{90}$ In addition the accused may have a weak alibi, corroborated only by witnesses of questionable character.

The judicial practice of reducing sentence following guilty pleas works a subtle coercion upon the defendant, incompatible with the constitutional guarantee of due process. ${ }^{01}$ The Supreme Court has held that a conviction will be invalidated if based upon a guilty plea which is the product of mental coercion. ${ }^{.2}$ While it is doubtful that a guilty plea could successfully be voided on the ground that sentencing procedure discriminated against the defendant demanding trial, nevertheless the pleader's freedom of choice is seriously inhibited when he is aware of such differentials in punishment. ${ }^{93}$

\section{Conclusion}

Judges have indicated that a defendant pleading not guilty may incur additional punishment because he displays an uncooperative attitude, commits perjury or asserts a frivolous defense at trial, reveals the circumstances of his crime, or does not contribute to the efficient administration of justice. Ex-

90. Evidence of a defendant's prior crimes is inadmissible to show a propensity toward criminal conduct. McCorArick, Eumence $\$ 157$ (1954). However if the accused puts his character in issue his prior crimes may be disclosed on cross-examination of his character witnesses. $I d$. $\S 158$. Furthermore if the defendant testifies, his past criminal conduct may be used to impeach his veracity as a witness. $I d$. $\S 157$. Though the evidence may nominally be introduced only for this purpose, it is almost certain to be prejudicial on the ultimate issue. Id. at 93-94; Note, 37 MINN. L. REv. 608, 617 (1953). If the defendant fails to testify, "his silence will adversely effect him." United States ex rel. Caminito v. Murphy, 222 F.2d 698, 703 (2d Cir.), cert. denied, 350 U.S. 896 (1955). In addition prior crimes may be used as direct evidence against a defendant if their introduction qualifies under one of the numerous exceptions to the general exclusionary rule. MCCoRmick, Evidence $\S 157$ (1954).

91. Due process of law is denied if a defendant is convicted on a coerced plea of guilty. Waley v. Johnston, 316 U.S. 101, 104 (1942) ; Behrens v. Hironimus, 166 F.2d 245, 247 (4th Cir. 1948) ; People v. Heirens, 4 Ill. 2d 131, 141, 122 N.E.2d 231, 237 (1954), ccrt. denicd, 349 U.S. 947 (1955) ; see Pennsylvania ex rel. Herman v. Claudy, 350 U.S. 116,118 (1956).

"[A]n accused who has been convicted on a plea of guilty induced by threats, promises and intimidation ... has been deprived of constitutional rights to the same extent as a person who has been convicted upon a confession obtained through coercion."

Behrens v. Hironimus, supra at 247.

92. Waley v. Johnston, supra note 91; see Pennsylvania ex rel. Herman v. Claudy, stipra note 91.

93. The language of some cases supports the contention that convictions based on guilty pleas should be constitutionally voided if the sentencing procedure awards a reduced sentence to a defendant pleading guilty. E.g., "A plea of guilty is involuntary when made under such inducements as would cause an innocent man to confess guilt." Palmer v. Cranor, 45 Wash. 2d 27\$, 282, 273 P.2d 985, 988 (1954); see 3 Wigmore, Evidence $\$ 824$, at 250-51 (3d ed. 1940) (showing similar standards are used for excluding confessions). 
amination of each of these rationales discloses imposing constitutional, statutory and policy weaknesses. Inherent in the practice of awarding reduced sentences following guilty pleas is discrimination-discrimination against the innocent defendant induced to plead guilty, and discrimination against the guilty defendant punished more severely than one committing the same crime and equally in need of reformation. Since only a minority of judges ignore the plea in determining sentence, ${ }^{94}$ and since the judges who do consider the plea disagree on its relative importance, defendants pleading guilty will receive unequal benefit, depending upon the individual practice of the court. In view of the inequities that the policy fosters, courts should not award sentencing concessions to defendants who plead guilty. ${ }^{95}$

94. 47 judges indicated that the plea was not a relevant factor in sentencing. "In my opinion it is not wise or fair to make a practice of imposing less severe sentences on defendants who plead guilty. To do so as an established practice acts as a measure of inducement to defendants to plead guilty in doubtful cases where, on a trial, they might have a reasonable chance of acquittal."

"The nature of the plea, guilty or not guilty, in my opinion should have no bearing upon the degree of punishment. Otherwise one would plead 'not guilty' knowing that more of a hazard was assumed than if a guilty plea was made. This is a form of coercion."

QUESTIONNAIRES.

95. "[P]robably the greatest weakness in the administration of criminal justice in the courts of the United States ... [is] the unfairness and injustice arising from the wide disparity in the sentences meted out by the federal judges . . . ."

Address by Warren Olney III, Assistant Att'y Gen., Crim. Div., Dep't of Justice, Los Angeles, Cal., Sept. 20, 1956. 